\title{
Influence of Alkaline-activator Content on the Compressive Strength of Aluminosilicate-based Geopolymer
}

\author{
Jin Tae Kim***, Dong Seok Seo*, Gab Joong Kim***, and Jong Kook Lee*,**, \\ *Department of Advanced Materials Engineering, Chosun University, Gwangju 501-759, Korea \\ **BK21 Education Center of Mould Technology for Advanced Materials \& Parts, Chosun University, Gwangju 501-759, Korea \\ ***ECONIX Co., Ltd, Hampeong 525-801, Korea \\ (Received November 17, 2009; Revised April 8, 2010; Accepted April 20, 2010)
}

\section{알루미노 실리케이트계 지오폴리머의 압축강도에 미치는 알카리 활성화제의 영향}

\author{
김진태**** 서동석* · 김갑중*** · 이종국****; \\ *조선대학교 신소재공학과 \\ **BK21 첨단소재부품 금형기술 인력양성사업단 \\ ***(주)에코닉스 \\ (2009년 11월 17일 접수 ; 2010년 4월 8일 수정 ; 2010년 4월 20일 승인)
}

\begin{abstract}
Portland cement has been restricted in applications to ecological area because of its environmental harmfulness and the $\mathrm{CO}_{2}$ emission during a production process. Geopolymer materials attract some attention as an inorganic binder due to their superior mechanical and eco-friendly properties. In this study, geopolymer-based cement was prepared by using aluminosilicate minerals (flyash, meta-kaolin) with alkaline-activators and its compressive strength with concentration of alkaline-activators was investigated. Aluminosilicate-based geopolymers were obtained by mixing aluminosilicate minerals, alkaline solution $(\mathrm{NaOH}$ or $\mathrm{KOH}$ with different concentration) and water-glass under the vigorous stirring for $20 \mathrm{~min}$. Compressive strength after curing at $30^{\circ} \mathrm{C}$ for 3 days increased with the concentration of alkaline-activator due to the enhanced polymerization of the aluminosilicate materials and dense microstructure. Aluminosilicate-based geopolymer cement using $\mathrm{KOH}$ as an alkaline-activator showed high compressive strength compared with $\mathrm{NaOH}$ activator. In addition, geopolymer cement using fly-ash as a raw material showed higher compressive strength than that of meta-kaolin.
\end{abstract}

Key words : Geopolymer cement, Aluminasilicate, Fly-ash, Meta-kaolin, Alkaline-activator

\section{1. 서 론}

지구온난화로 인한 각종 자연재해 발생빈도가 증가하 고 있는 가운데, 세계 각국에서는 지구온난화의 원인인 $\mathrm{CO}_{2}$ 의 발생량을 줄이기 위한 다양한 노력들이 이루어지 고 있다. 건축 및 토목 분야에서 흔히 사용되는 포틀랜드 시멘트는 지난 수백 년간 건축, 토목재료에 있어서 가장 많이 사용된 무기결합재인데, 원료가 많고 값이 싸다는 장점에도 불구하고, 시멘트 제조과정에서 발생하는 $\mathrm{CO}_{2}$ 발생량이 전 세계 $\mathrm{CO}_{2}$ 배출량 중 큰 비중을 차지하고 있 기 때문에 각국별로 시멘트 생산량을 제한하려는 시도가 진행되고 있다. ${ }^{1,2)}$

\footnotetext{
${ }^{\dagger}$ Corresponding author : Jong Kook Lee

E-mail : jklee@chosun.ac.kr
}

Tel : +82-62-230-7202 Fax : +82-62-232-2474
이산화탄소의 배출을 줄이기 위한 노력의 일환으로 포 틀랜드 시멘트를 대체할 수 있는 새로운 무기결합재의 개 발에 많은 연구가 이루어지고 있는데, 그 중에서도 알루 미노 실리케이트계 지오폴리머는 우수한 기계적 특성과 친환경 물성으로 인하여 포틀랜드 시멘트를 대체할 수 있 는 재료로 많은 주목을 받고 있다. 또한 알루미노 실리케 이트계 지오폴리머는 전 세계적으로 발생되는 산업부산 물(플라이애시, 고로 수쇄 슬래그 등)을 주요 원료로 사 용하기 때문에 자원의 재활용 측면에서 매우 중요한 연 구로 인식되고 있다. ${ }^{3)}$

지오폴리머는 $\mathrm{Al}$ 과 $\mathrm{Si}$ 원소가 함유된 점토계 세라믹 분 말을 강알칼리성 용액의 조건에서 혼합하여 중합 반응시 킨 것으로 알칼리성 알루미노 실리케이트 시멘트의 일종 이다. 지오폴리머의 장점으로는 우수한 내열성, 단열성, 내산성, 저수축성 등이 있으며, 이 외에도 동결융해 저항 성, 부식 및 풍화 저항성 등이 있다. 또한, 치밀성이 높고 
Table 1. Starting Composition of Geopolymers

\begin{tabular}{cccc}
\hline \multirow{2}{*}{ Specimen } & \multicolumn{3}{c}{ Composition } \\
\cline { 2 - 4 } & Starting materials $(350 \mathrm{~g})$ & Alkali activator $(125 \mathrm{~g})$ & Water glass $(25 \mathrm{~g})$ \\
\hline FGK & Fly-ash & $\mathrm{KOH}(3,6,9,12 \mathrm{M})$ & Water glass \\
MGK & Fly-ash & $\mathrm{NaOH}(3,6,9,12 \mathrm{M})$ & Water glass \\
MGN & Meta-kaolin & $\mathrm{KOH}(3,6,9,12 \mathrm{M})$ & Water glass \\
\end{tabular}

수밀성이 있으며, 접착성이 우수하고 빠른 시간 내에 응 결이 가능하다. ${ }^{4,5}$ 알칼리 활성제로는 $\mathrm{NaOH}$ 또는 $\mathrm{KOH}$ 가 주로 사용되는데, 단순히 $\mathrm{SiO}_{2}, \mathrm{Al}_{2} \mathrm{O}_{3}$ 와 활성제와의 조합 만으로는 기존 포틀랜드 시멘트를 대체할만한 물성이 나 오지 않기 때문에 효과적인 품질향상을 위해 많은 연구 가 진행되고 있다. ${ }^{6}$

상온에서 입자간 결합이 가능한 무기결합재 시멘트 제 조에 대한 연구는 포틀랜드 시멘트 제조 시 요구되는 대 량의 에너지를 절약할 수 있을 뿐만 아니라 발생되는 $\mathrm{CO}_{2}$ 배출량도 크게 줄일 수 있으며, 다양한 산업 부산물을 활 용할 수 있다. ${ }^{7)}$

산업부산물 중 플라이애시나 메타카올린의 경우, 실온 및 대기압 조건에서 물과 반응하여 초기에는 빠르게 분 해되나, 낮은 용해도를 갖는 분해물질이 원료물질 위에 침적하여 플라이애시 또는 메타카올린의 지속적인 분해 반응을 차단하거나 반응속도를 느리게 하여 무기결합재 로서의 특성을 크게 약화시키게 된다. 따라서 무기결합재 의 특성을 향상시켜 시멘트 산업에 응용하기 위해서는 플 라이애시 또는 메타카올린의 중합반응을 지속적으로 유 지할 수 있는 활성화 공정이 필요하며, 이를 위한 방법으 로 고농도의 알칼리 용액이 활성화제로 사용되고 있다. ${ }^{8-10)}$

본 연구에서는 포틀랜드 시멘트의 대체소재로서 지오 폴리머 무기결합재의 활용 가능성을 알아보고자 하였으 며, 이를 위하여 알칼리 활성제의 종류 및 몰 농도에 따 른 지오폴리머 시멘트의 미세조직 변화 및 압축강도에 미 치는 영향에 대하여 실험하였다.

\section{2. 실험 방법}

본 실험에서는 지오폴리머를 제조하기 위한 출발원료 로 플라이애시와 메타카올린을 이용하였다. 플라이애시는 경남 하동에 위치한 화력발전소인 KOREA SOUTHERN POWER로부터 화력 발전의 부산물로 추출된 플라이애시 를 이용하였고, 메타카올린은 시중에서 구입한 상용분말 (CEMIUS KOREA)을 이용하였다. 사용된 플라이애시 및 메타카올린 분말에 대한 조성 및 분말 특성을 확인하기
위하여 X-ray 회절 분석 및 SEM 분석을 실시하였다.

지오폴리머는 플라이애시 또는 메타카올린 분말 $350 \mathrm{~g}$ 을 기본으로 합성하였는데, 여기에 적정한 작업성을 얻기 위해 물 유리 $25 \mathrm{~g}$ 을 첨가하였고, 반응 활성화제로 알칼 리 자극제 $(w a t e r+\mathrm{NaOH}, \mathrm{KOH}) 125 \mathrm{~g}$ 을 각각 첨가하였다. 알칼리 자극제로는 $\mathrm{NaOH}$ 와 $\mathrm{KOH}$ 를 사용하였는데, 사전 에 3, 6, 9 그리고 $12 \mathrm{M}$ 로 농도를 조절하여 사용하였다. Table 1에 배치조성에 따른 시편의 종류를 나타내었다.

지오폴리머 합성 순서는 우선 각각의 몰 농도를 갖는 알칼리 수용액에 물 유리를 첨가한 후 교반기에서 10 분 간 혼합하여 용액을 제조한 다음, 이 용액을 플라이애시 와 메타카올린에 각각 첨가하여 지오폴리머 슬러리를 제 조하였다. 재료 간의 충분한 혼합을 위하여 믹서기를 이 용하여 약 10 분간 혼련시켜 슬러리를 제조하였으며, 제조 된 지오폴리머 슬러리를 $50 \times 100 \mathrm{~mm}$ 플라스틱 몰드에 넣 고 충진시켜 성형시편을 제조하였다. 제조된 성형 시편을 항온 항습 건조기에 넣은 다음, $80^{\circ} \mathrm{C}$ 인 고온에서 약 3 일 간 양생하여 고형성의 지오폴리머 시멘트 시편을 제조하였다.

플라스틱 몰드로부터 각각의 시편당 5 개의 탈형한 시 편을 사용하여 UTM으로 압축강도를 측정하여 분석하였 으며, 출발원료의 종류와 알칼리 활성제의 몰 비에 따라 분말과 시편을 $\mathrm{XRD}$ 로 상분석을 행하였고, $\mathrm{SEM}$ 으로 파 단면을 관찰하여 지오폴리머 시멘트의 미세구조를 관찰 하였다.

\section{3. 결과 및 고찰}

출발원료인 플라이애시 및 메타카올린 분말을 $\mathrm{XRD}$ 로 상분석 한 후, $\mathrm{SEM}$ 으로 미세구조를 관찰하여 Figs. 1 및 2에 나타내었다. 플라이애시 분말의 미세구조를 관찰한 결과, $1 \mu \mathrm{m}$ 이하의 미립자와 약 $15 \mu \mathrm{m}$ 크기의 구형입자 가 bimodal 형태로 혼재하였고, 구형의 입자와 불규칙 형 상을 갖는 약한 응집입자도 관찰되었다 (Fig. 1(a)). XRD 분석 결과, 플라이애시 분말은 물라이트 $\left(2 \mathrm{SiO}_{2} \cdot 3 \mathrm{Al}_{2} \mathrm{O}_{3}\right)$ 와 석영의 결정상으로 이루어져 있었으며, 약간의 비정질상 이 $2 \theta=20 \sim 40^{\circ}$ 의 범위에서 관찰되었다(Fig. 1(b)). 

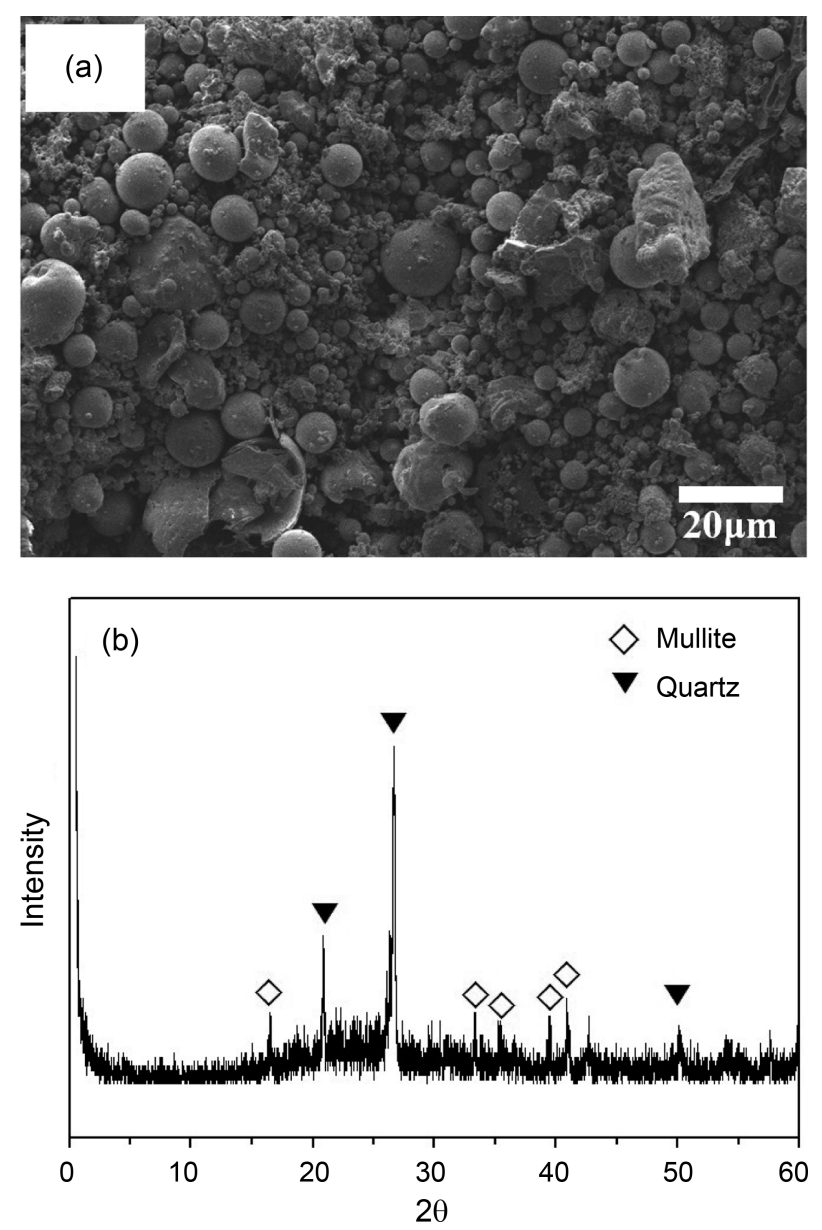

Fig. 1. Microstructure and phases of starting fly-ash powder.

메타카올린 분말의 경우 대부분 $1 \mu \mathrm{m}$ 이하의 미립자로 구성되어 있었으나 그 크기와 모양은 다소 불규칙하였다 (Fig. 2(a)). XRD 상분석 결과 메타카올린도 물라이트와 석영의 결정상으로 이루어져 있었고, 약간의 비정질상이 관찰되었다(Fig. 2(b)).

플라이애시 출발원료에 알칼리 활성화제인 $\mathrm{KOH}$ 를 농 도 별로 첨가한 후 양생하여 제조한 지오폴리머 시멘트 의 미세구조를 Fig. 3에 나타내었다. 알칼리 활성화제의 몰 비가 증가함에 따라 구형 형태의 입자가 크게 감소하 고, 전체적인 미세구조가 더욱 치밀한 형태를 나타내었다. 알칼리 농도가 가장 낮은 $3 \mathrm{M}$ 의 $\mathrm{KOH}$ 를 첨가한 $\mathrm{FGK}-3$ 시편의 경우, 용해 및 중합반응이 제대로 일어나지 않아 출발 원료에서 보였던 커다란 구형 입자가 그대로 존재 하였으며, 이들 입자 사이에도 빈 공간이 많이 남아있어 치밀성이 떨어지는 것으로 나타났다(Fig. 3(a)). $6 \mathrm{M}$ 의 $\mathrm{KOH}$ 를 알칼리 활성화제로 첨가한 시편부터 용해반응에 의하여 시편 내에 존재하는 구형 입자가 다수 사라졌으 며, 아울러 $\mathrm{Al}^{3+}$ 이온과 $\mathrm{Si}^{4+}$ 이온들의 중합반응이 증가하 여 미세구조는 더욱 치밀화된 형태를 나타내었다. 이러한
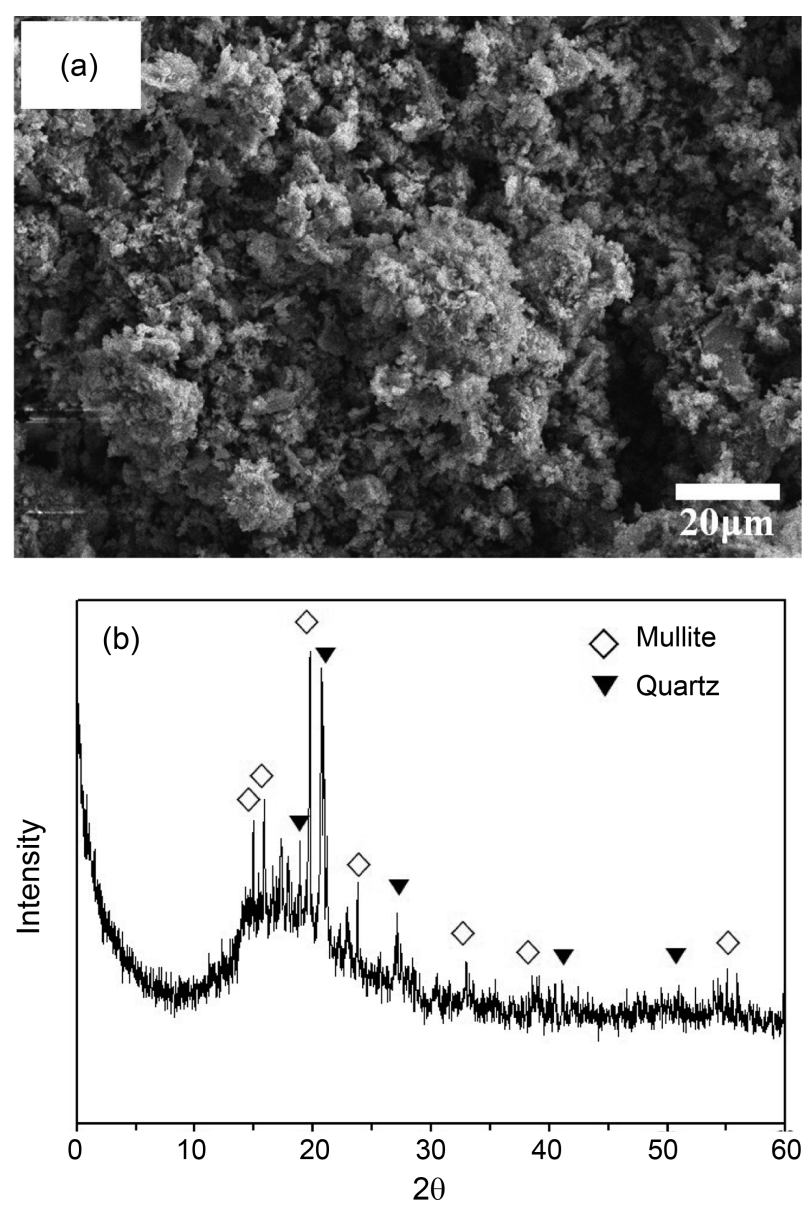

Fig. 2. Microstructure and phases of starting meta-kaolin powder.
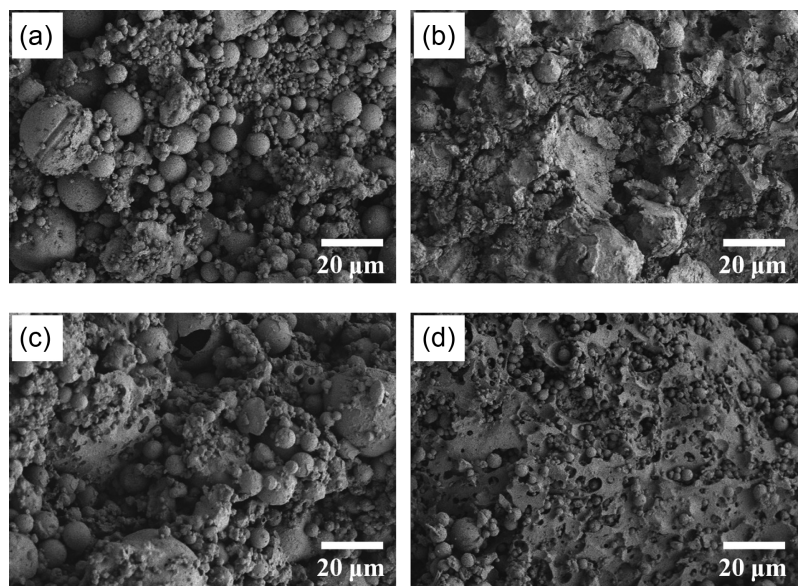

Fig. 3. Microstructures of fly-ash based FGK geopolymer cement prepared using (a) $3 \mathrm{M}$, (b) $6 \mathrm{M}$, (c) $9 \mathrm{M}$, and (d) $12 \mathrm{M} \mathrm{KOH}$ activator.

현상은 알칼리 활성화제의 농도가 증가할수록 좀더 두드 러지게 나타나는 것을 알 수 있는데(Fig. 3 (b) (d)), $12 \mathrm{M}$ 의 $\mathrm{KOH}$ 를 활성화제로 첨가한 FGK-12 시편의 경우, 용 

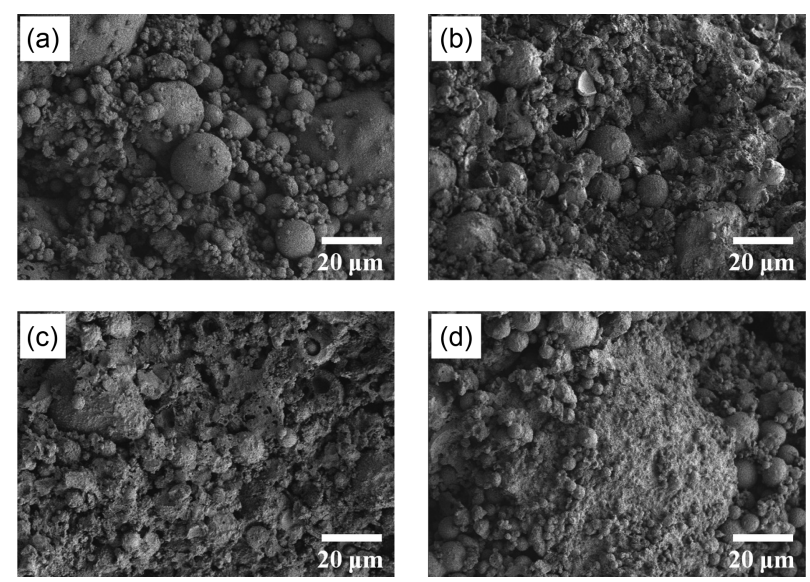

Fig. 4. Microstructures of fly-ash based FGN geopolymer cement prepared using (a) $3 \mathrm{M}$, (b) $6 \mathrm{M}$, (c) $9 \mathrm{M}$, and (d) $12 \mathrm{M} \mathrm{NaOH}$ activator.

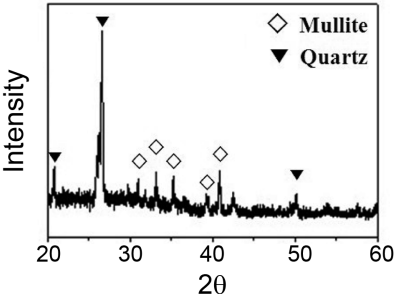

(a)

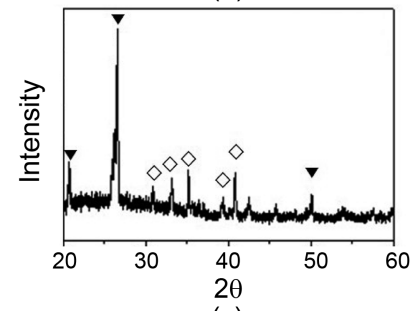

(c)

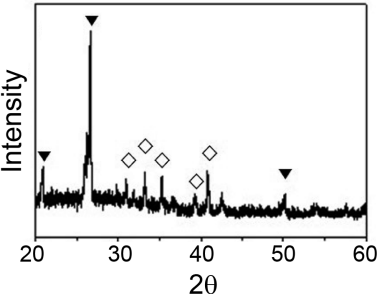

(b)

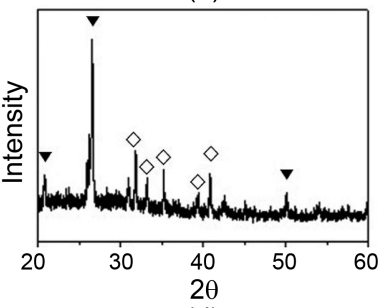

(d)
Fig. 5. XRD patterns of fly-ash based FGK geopolymer cement prepared using (a) $3 \mathrm{M}$, (b) $6 \mathrm{M}$, (c) $9 \mathrm{M}$, and (d) $12 \mathrm{M}$ $\mathrm{KOH}$ activator.

해 및 중합반응이 크게 일어나 미세구조가 치밀하고 입 자간에 강한 결합을 나타내었다 (Fig. 3(d)).

플라이애시 출발원료에 $\mathrm{NaOH}$ 알칼리 활성화제를 사용 하여 제조한 지오폴리머 시멘트의 미세구조를 Fig. 4에 나타내었다. $\mathrm{KOH}$ 를 알칼리 활성제로 사용한 지오폴리머 시편과 마찬가지로 $\mathrm{NaOH}$ 의 몰 비가 증가함에 따라 보다 치밀한 미세구조를 나타내었다. 치밀도가 가장 높은 12 $\mathrm{M}$ 의 $\mathrm{NaOH}$ 를 첨가한 $\mathrm{FGN}-12$ 지오폴리머의 경우 $\mathrm{KOH}$ 를 사용한 시편에 비하여 치밀성이 다소 떨어졌는데, 이로 인하여 둥근 형태의 플라이애시 입자가 다수 관찰되었고, 시편의 표면은 다소 거친 형상을 나타내었다 (Fig. 4(d)).

알칼리 활성화제의 종류 및 첨가량에 따른 지오폴리머 시멘트의 중합반응 정도를 알아보기 위하여 XRD 상분석

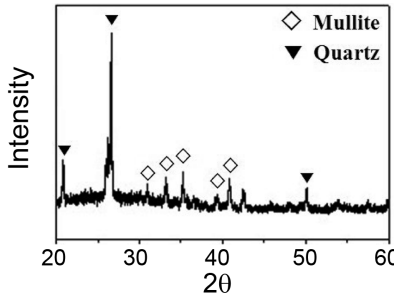

(a)

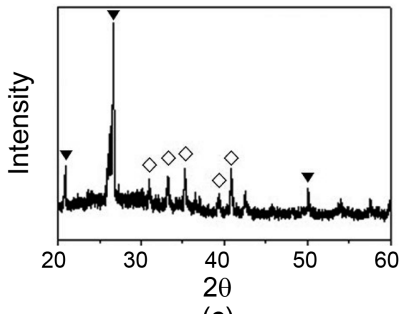

(c)

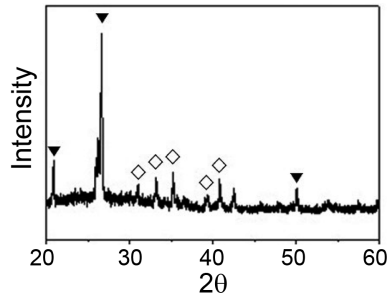

(b)

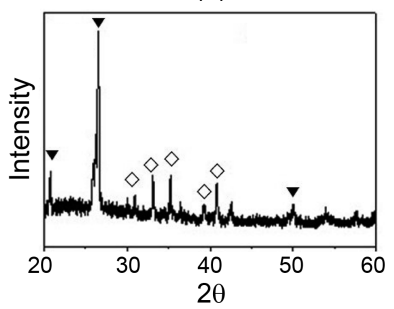

(d)
Fig. 6. XRD patterns of fly-ash based FGN geopolymer cement prepared using (a) $3 \mathrm{M}$, (b) $6 \mathrm{M}$, (c) $9 \mathrm{M}$, and (d) $12 \mathrm{M}$ $\mathrm{NaOH}$ activator.
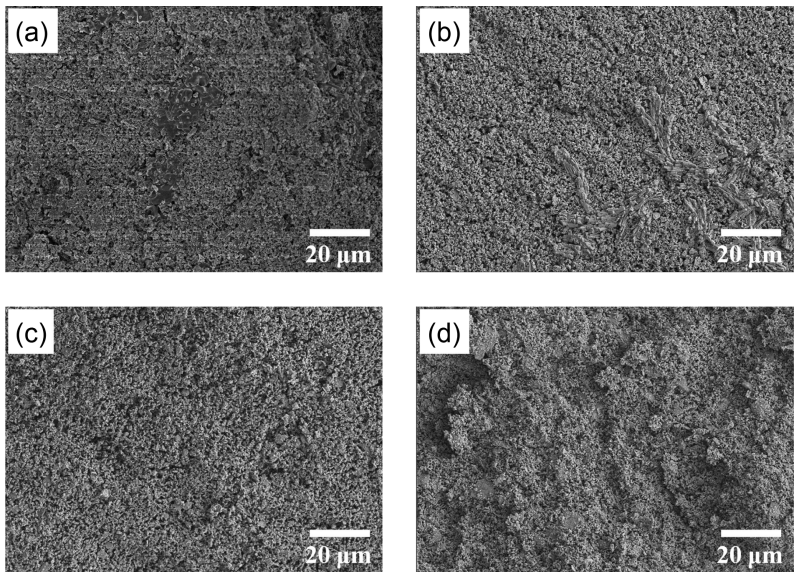

Fig. 7. Microstructures of meta-kaolin based MGK geopolymer cement prepared using (a) $3 \mathrm{M}$, (b) $6 \mathrm{M}$, (c) $9 \mathrm{M}$, and (d) $12 \mathrm{M} \mathrm{KOH}$ activator.

을 행하였는데, 그 결과를 Fig. 5와 Fig. 6에 각각 나타내 었다. 플라이애시를 출발 원료로 한 지오폴리머의 경우 알칼리 활성화제의 종류 및 첨가량에 관계없이 지오폴리 머 원료분말의 상과 크게 다르지 않았는데, 이는 중합반 응으로 형성된 비정실상의 회절강도에 비하여 결정상인 석영과 mullite의 회절강도가 상대적으로 높기 때문인 것 으로 보인다. 이에 따라 XRD 분석으로는 플라이애시와 알칼리 활성화제의 중합반응 정도나 이에 따른 비정질상 의 생성 양을 결정할 수 없었다.

Fig. 7에 $\mathrm{KOH}$ 를 알칼리 활성화제로 사용한 메타카올린 계 지오폴리머 시멘트의 미세구조를 나타내었는데, $\mathrm{KOH}$ 활성화제의 농도가 증가할수록 미세구조는 중합반응의 증 가에 의해 더욱 치밀하였다. 활성화제의 농도 증가에 따 

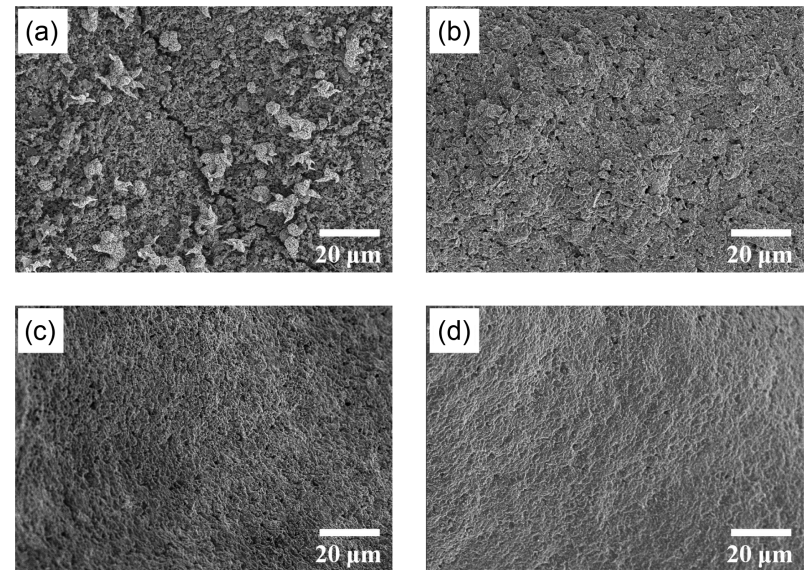

Fig. 8. Microstructures of meta-kaolin based MGN geopolymer cement prepared using (a) $3 \mathrm{M}$, (b) $6 \mathrm{M}$, (c) $9 \mathrm{M}$, and (d) $12 \mathrm{M} \mathrm{NaOH}$ activator.

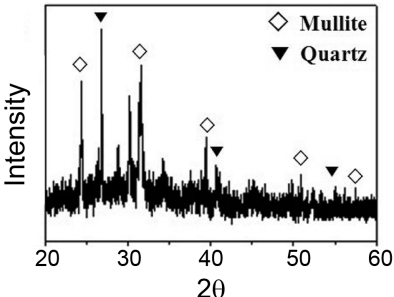

(a)

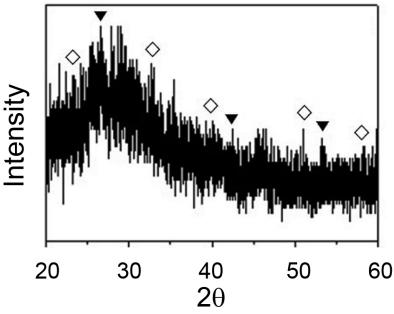

(c)

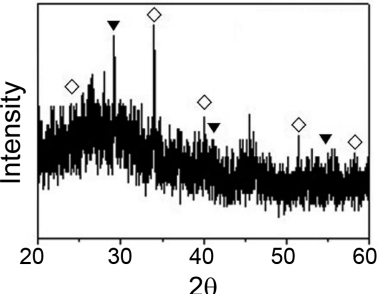

(b)

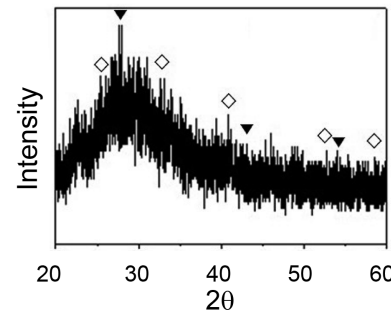

(d)
Fig. 9. XRD patterns of meta-kaolin based MGK geopolymer cement prepared using (a) $3 \mathrm{M}$, (b) $6 \mathrm{M}$, (c) $9 \mathrm{M}$, and (d) $12 \mathrm{M} \mathrm{KOH}$ activator.

른 미세구조의 치밀화 경향은 $\mathrm{NaOH}$ 를 알칼리 활성제를 사용하여 제조한 메타카올린계 지오폴리머에서 더욱 뚜 렷하였는데(Fig. 8), 첨가된 $\mathrm{NaOH}$ 의 몰 비가 증가할수록 기공이 크게 감소하였고, 입자는 더욱 미세한 형상을 나 타내었다.

메타카올린 계 지오폴리머 시편을 XRD로 상분석한 결 과(Figs. 9, 10), 중합반응에 의한 비정질상의 증가는 알칼 리 활성화제의 종류보다는 농도에 따라 크게 변화하였다. 전체적으로 비정질상의 증가는 플라이애시계 지오폴리머 보다 높게 나타났으며, 특히 $6 \mathrm{M}$ 이상의 알칼리 활성화 제를 첨가한 시편부터 크게 나타났고, $9 \mathrm{M}$ 이상의 알칼 리 활성화제를 첨가한 지오폴리머의 경우 메타카올린에 서 보이던 결정상 피크가 모두 사라지고, 비정질 형태의

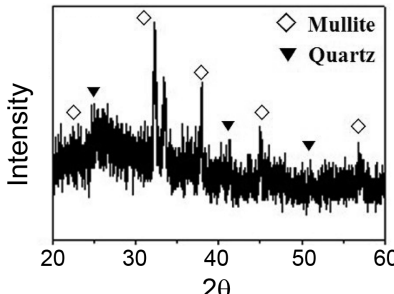

(a)

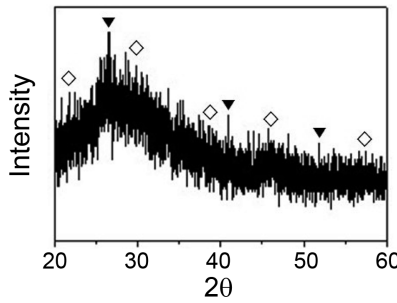

(c)

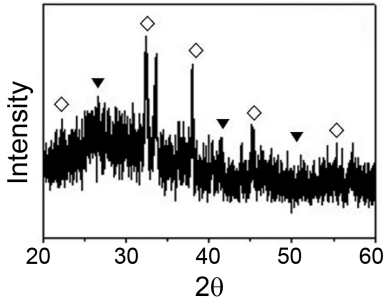

(b)

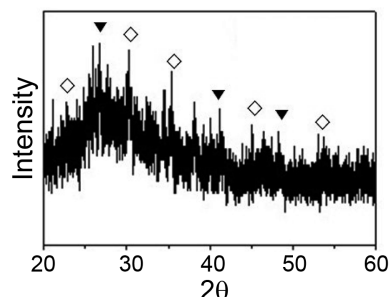

(d)
Fig. 10. XRD patterns of meta-kaolin based MGN geopolymer cement prepared using (a) $3 \mathrm{M}$, (b) $6 \mathrm{M}$, (c) $9 \mathrm{M}$, and (d) $12 \mathrm{M} \mathrm{NaOH}$ activator.

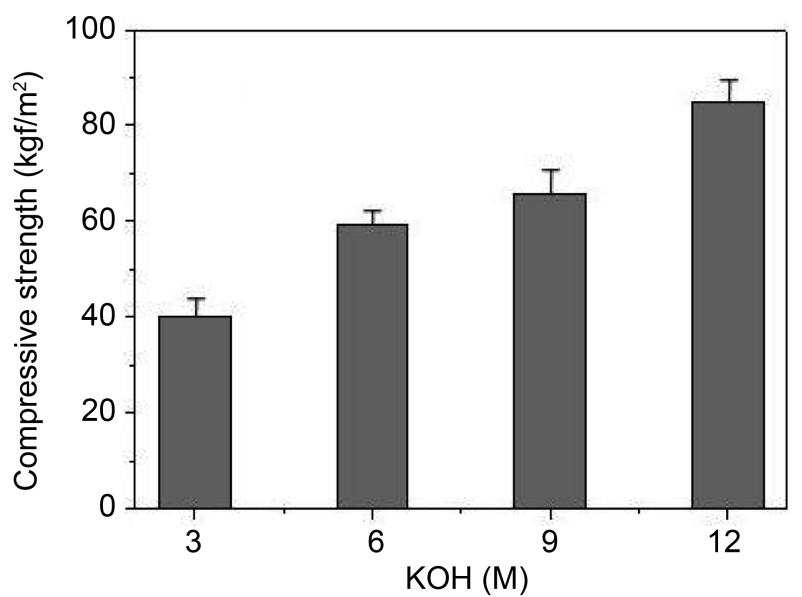

(a)

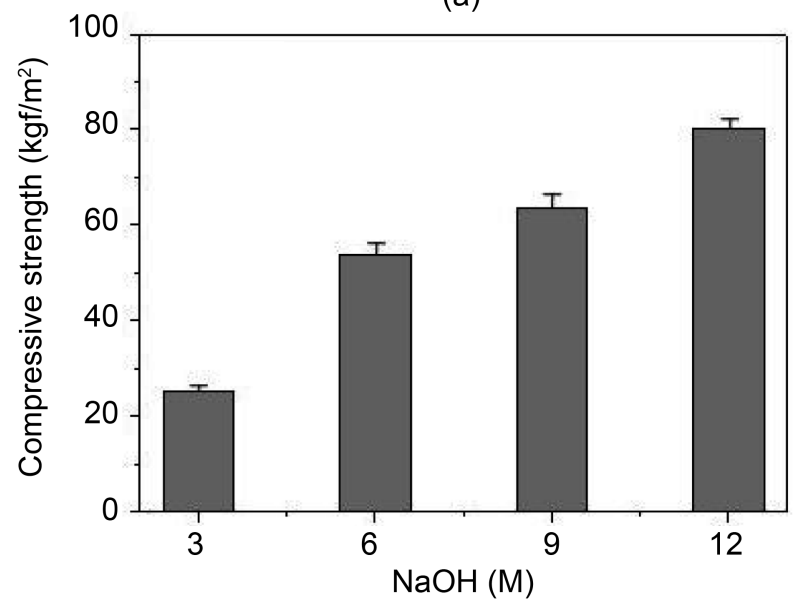

(b)

Fig. 11. Compressive strength of fly-ash based geopolymer cement with the concentration of alkali activator; (a) FGK and (b) FGN. 


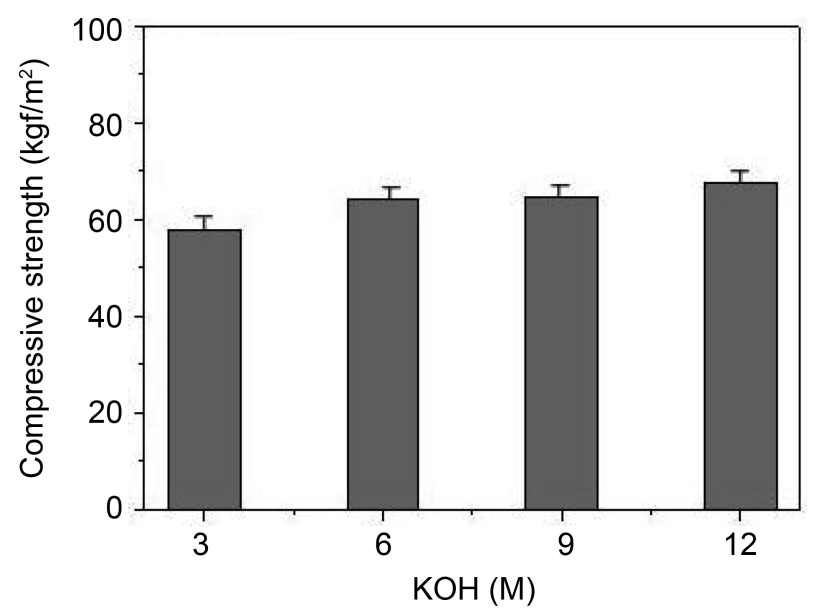

(a)

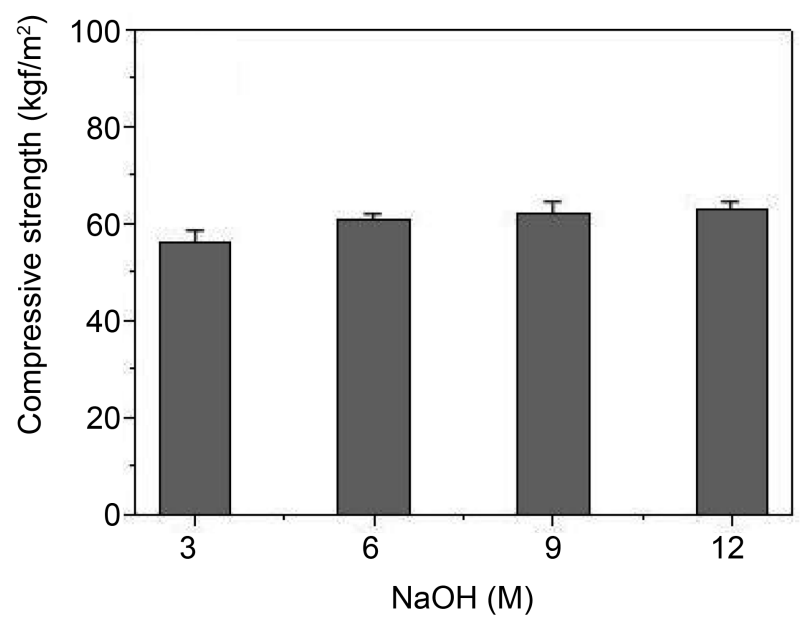

(b)

Fig. 12. Compressive strength of meta-kaolin based geopolymer cement with the concentration of alkali activator; (a) MGK and (b) MGN.

피크만 존재하였다.

제조한 지오폴리머 시멘트의 압축강도를 측정한 결과, 압축강도는 출발원료의 종류, 알칼리 활성화제의 종류 및 농도에 따라 변화하였다. 플라이애시계 지오폴리머의 압 축강도는 알칼리 활성제의 종류보다는 농도에 의존하였 는데, 알칼리 활성화제의 농도가 증가할수록 중합반응의 증가 및 미세구조의 치밀화에 의해 압축강도는 크게 향 상되었다(Fig. 11). $\mathrm{KOH}$ 를 알칼리 활성화제로 첨가한 경 우가 $\mathrm{NaOH}$ 를 첨가한 시편보다 압축강도가 다소 높았는 데, 이는 중합반응에 따른 미세구조의 치밀화가 증가하였 기 때문인 것으로 보인다. 또한 중합반응으로 형성된 비 정실상의 회절강도에 비하여 결정상인 석영과 mullite의 회절강도가 상대적으로 높기 때문으로 사료된다. 플라이 애시계 지오폴리머의 가장 높은 압축강도는 $12 \mathrm{M} \mathrm{KOH}$ 를 알칼리 활성화제로 사용한 시편에서 얻어졌는데, 약
$85 \mathrm{kgf} / \mathrm{m}^{2}$ 의 압축강도를 나타내었다.

플라이애시계 지오폴리머와는 달리 메타카올린계 지오폴 리머의 경우 (Fig. 12), 알칼리 활성화제의 종류 및 농도가 압축강도에 미치는 영향은 적은 것으로 나타났다. 대체적 으로 알칼리 활성제의 몰 농도가 증가 할수록 압축 강도가 약간 증가하였지만 그 차이가 매우 적은 것으로 나타났다. $\mathrm{KOH}$ 를 활성화제로 사용한 경우가 $\mathrm{NaOH}$ 를 사용한 경우보 다 압축강도가 약간 증가하였지만 그 차이 또한 미미하였 다. 전체적으로 메타카올린계 지오폴리머 시멘트의 압축강 도는 결합성의 중합반응이 크게 진행되었음에도 불구하고 그 크기가 $57 \sim 67 \mathrm{kgf} / \mathrm{m}^{2}$ 로 낮게 나타났는데, 이는 메타카올 린 지오폴리머의 경우 대부분 강도가 떨어지는 점토질이 주성분으로 구성되었기 때문인 것으로 판단되며, 메타카올 린에서 보이던 결정상 피크가 모두 사라지고, 비정질 형태 의 피크만 존재하기 때문으로 보인다. 반면에 플라이애시 계 지오폴리머 시멘트의 경우 강도가 큰 물라이트와 석영 이 지오폴리머에 의해 결합되어 있는 복합체 구조이기 때 문에 압축강도가 크게 나타난 것으로 보인다.

\section{4. 결 론}

출발원료 및 알칼리 활성제를 달리한 지오폴리머 시멘 트를 제조한 다음, 이들 변수가 지오폴리머 시멘트의 미 세구조와 압축강도에 미치는 영향에 대하여 고찰하였다. 그 결과 플라이애시를 출발원료로 하여 제조한 지오폴리 머 시멘트의 경우 알칼리 활성화제의 농도가 증가함에 따 라 중합반응이 증가하여 미세구조가 균질하고 압축강도 가 점차적으로 증가하였으며, $\mathrm{KOH}$ 알칼리 활성화제를 첨 가제로 사용한 지오폴리머 시멘트의 압축강도가 $\mathrm{NaOH}$ 를 사용한 경우보다 높게 나타남을 알 수 있었다. 최대 압축 강도는 $\mathrm{KOH} 12 \mathrm{M}$ 을 알칼리 활성화제로 사용한 시편에 서 나타났는데, 이때의 압축강도는 약 $85 \mathrm{kgf} / \mathrm{m}^{2}$ 이었다. 메 타카올린을 출발원료로 사용한 경우 전체적으로 중합반 응은 크게 진행되었으나 압축강도는 비교적 낮은 값인 $57 \sim 67 \mathrm{kgf} / \mathrm{m}^{2}$ 을 나타내었고, 알칼리 활성화제의 농도나 종류에 관계없이 거의 비슷한 값을 나타내었다.

\section{Acknowledgment}

본 연구는 교육과학기술부와 한국산업기술진흥원의 지 역혁신인력양성사업으로 수행된 연구결과입니다.

\section{REFERRENCES}

1. P. Duxson, J. L. Provis, G. C. Lukey, and J. S. J. Van Deventer, "The Role of Inorganic Polymer Technology in the Development of Green Concrete," Cem. Concr. Res., 37 [12] 1590-97 (2007). 
2. J. Temuujin and A. van Riessen, "Effect of Fly Ash Preliminary Calcinations on the Properties of Geopolymer," $J$. Hazard. Mater., 164 [2-3] 634-39 (2008).

3. Q. Zhao, B. Nair, T. Rahimian, and P. Balaguru, "Novel Geopolymer Based Composites with Enhanced Ductility," $J$. Mater. Sci., 42 [9] 3131-37 (2007).

4. K. Komnitas and D. Zaharaki, "Geopolymerrisation; A review and Prospects for the Minerals Industry," Miner. Eng., 20 [14] 1261-77 (2007).

5. L. Provis, C. Z. Yong, P. Duxson, and J. S. J. Van Deventer, "Correlating Mechanical and Thermal Properties of Sodium Silicate-Fly Ash Geopolymer,” J. Mater. Sci., 336 [1-3] $57-$ 63 (2009)

6. D. Panias, I. P. Giannopoulou, and T. Perraki, "Effect of Synthesis Parameters on the Mechanical Properties of Fly Ash-Based Geopolymers," Colloid Surf. A-Physicochem.
Eng. Asp., 301 [1-3] 246-54 (2007).

7. J. L. Bell, P. E. Driemeyer, and W. M Kriven, "Formation of Ceramics from Metakaolin-Based Geopolymers: Part 1-CSBased Geopolymer," J. Am. Ceram. Soc., 92 [1] 1-8 (2008).

8. H. C. Wu and P. Sun, "New Building Materials from Fly Ash-Based Lightweight Inorganic Polymer," Constr. Build. Mater., 21 [1] 211-17 (2007).

9. H. S. Park, D. W. Yoo, S. H. Byun, and J. T. Song, "Rheological Properties of Ordinary Portland Cement: Blast Furnace Slag Fly Ash Blends Containing Ground Fly Ash," $J$. Kor. Ceram. Soc., 46 [1] 58-68 (2009).

10. J. G. S. V. Jaarsveld, J. S. J. V. Deventer, and G. C. Lukey, "The Effect of Composition and Temperature on the Properties of Fly Ash and Kaolinite-Based Geopolymers," Chem. Eng. J., 89 [1-3] 63-73 (2002). 